DIGITAL COMMONS
@ UNIVERSITY OF SOUTH FLORIDA

Volume 7

Issue 2 Volume 7.2 (Fall 2017)

\section{ABO: Interactive Journal for Women in the Arts, 1640-1830}

2017

\title{
Women, Gender and the Arts: Intersections, Differences and Connections
}

\author{
Mona Narain \\ Texas Christian University, m.narain@tcu.edu
}

Follow this and additional works at: https://digitalcommons.usf.edu/abo

Part of the Dramatic Literature, Criticism and Theory Commons, Educational Methods Commons, Feminist, Gender, and Sexuality Studies Commons, and the Literature in English, British Isles Commons

\section{Recommended Citation}

Narain, Mona (2017) "Women, Gender and the Arts: Intersections, Differences and Connections," $A B O$ : Interactive Journal for Women in the Arts, 1640-1830: Vol.7: Iss.2, Article 2.

http://doi.org/10.5038/2157-7129.7.2.1167

Available at: https://digitalcommons.usf.edu/abo/vol7/iss2/2

This Scholarship is brought to you for free and open access by Digital Commons @ University of South Florida. It has been accepted for inclusion in ABO: Interactive Journal for Women in the Arts, 1640-1830 by an authorized administrator of Digital Commons @ University of South Florida. For more information, please contact digitalcommons@usf.edu. 


\section{Women, Gender and the Arts: Intersections, Differences and Connections \\ Creative Commons License \\ (c) () () (9)}

This work is licensed under a Creative Commons Attribution-Noncommercial 4.0 License 
Women, Gender and the Arts: Intersections, Differences, and Connections

We admire and celebrate the seventeenth-century woman writer Aphra Behn (1640-1689) for her prolific and diverse writing. Her work ranges from poems, plays, translations, prose to novellas. It depicts nuns torn by passionate desire, philosophical courtesans, an African prince who is also slave, and characters who perform multiple identities and sexualities. Behn charts early modern connections between London, Coramantien in Africa (modern day Gold Coast in Ghana), Surinam and the Pacific Islands. She sends her characters all across Europe and parts of the known globe, connecting stories, identities and histories. At the same time, she reveals their efforts to hide from relationships in narratives of loss and their efforts to disguise their past for new beginnings. As an open-access, peer-reviewed digital journal, ABO: Interactive Journal for Women and the Arts 1640-1830, draws inspiration from Aphra Behn's life and works. It is committed in its content and its digital format to crossing borders and examining the multiple complex intersections that formed the early modern period and the importance of these intersections for us. Through its innovative format of juxtaposing scholarly essays with articles about pedagogy, showcasing digital work about both scholarship and pedagogy, and its commitment to constructive dialogue between author, reviewer, and reader, the journal connects the overlapping spaces of what many consider separate circles of knowledge production. Yet, $A B O$ carefully acknowledges the validity and integrity of the differences in various kinds of scholarship. By doing so, $A B O$ has sought to extend and enhance the idea of what is knowledge production and what is scholarship.

Since its inception under Kirsten Saxton, the inaugural scholarship editor, $A B O$ 's scholarship section has carved out a distinct trajectory, publishing innovative essays that analyze the dynamic interaction between identities, sexualities, gender, genre and class. These essays have attracted readers from all over the world. $A B O$ has responded well to Laura Rosenthal's call to Eighteenth-Century Studies scholars to detail in fuller ways "the impact, engagements, and intellectual propositions of women writers," in ways that exceed the "paradigms that allowed us to take them seriously in the first place" (11).

As $A B O$ 's incoming scholarship editor, I want to build on the strength of the journal's distinctiveness and innovation. I invite the journal's authors and readers to continue to dig deeper into the intersections of old and new notions of race; nations and globality; varied spaces, virtual, metaphorical, digital and geographical; emerging areas of study such as disability studies, climate science, studies of material objects and their circulation, cosmopolitanisms, food studies, and animal studies, to name just a few, with the important categories of woman, gender, sexuality, identity and class in early modern literature and the arts. Contemporary scholarship has been enriched by Kimberlé Williams Crenshaw's concept of “intersectionality.” Initially theorized as a methodology to read black women's layered experiences and subjectivities, recently Sumi Cho, Kimberlé Williams Crenshaw and Leslie McCall have observed that 
intersectionality has become a traveling theory that emerges in a variety of discursive spaces. ${ }^{1}$ As a theoretical framework, intersectionality allows us to see how varied experiences and subject positions crisscross each other, revealing similarities as well as differences that are often mobilized at the same time. Intersectionality is a methodology, among other viable methodologies, particularly well-suited to interdisciplinary and disciplinary approaches that acknowledge the complexity of studying women and gender. Let us then continue to re-read and newly read early modern texts and art through a revised and expanded notion of global intersectionality, further deepening our analysis, without losing sight of intersectionality's crucial illustration of the relationship between gender and race in specific cultural contexts or its emphasis on the subaltern.

The connected histories and intersectionalities of the early modern period join with our own world and have important ramifications. Historian Sanjay Subrahmanyam has argued that "connected histories" illuminate the fact that though mental and material constructs are grounded in local concerns and expressions, cultural zones were, and still are, highly permeable. Simply put, ideas came in and flowed beyond temporal, political, and geographic boundaries. For example, how did early modern writers and artists delineate new and different encounters beyond their local context in different art forms? How did the long eighteenth century conceptualize immigration, asylum, and refugees, and the gendered nature of these concepts, charting inward flows into nations and cultures? How might the study of gender concepts in eighteenth-century India reveal their influence on writers like Elizabeth Hamilton and Sydney Owenson, which allowed these women to add new elements in their progressive arguments about gender to the British public? These were important questions in the past, yet perhaps even more so now. Through connected histories we can delineate new and extended pathways for the circulation of ideas in the early modern world, for example, analyzing how the sea routes of the Black Atlantic and the Indian Ocean were always deeply intertwined. What might that mean for extending the analysis of Aphra Behn's Oroonoko based on the context of the Atlantic slave routes and the conflicts between the Dutch and the English, but to also include the politics of European commerce between Southeast Asia and Africa? How might we depict these connections textually and/or through GIS mapping technologies? To this end, in addition to publishing individual highquality submissions, in future years $A B O$ will sponsor special issues that chart these "insideoutside" cultural flows and intersections both in form and content. However, analyzing connecting histories does not mean flattening out the sites of geographical, cultural and historical divergences. ${ }^{2}$ Indeed, the early modern period serves as a lesson in defamiliarization for our time and demands that we recognize and acknowledge radical differences. I hope our authors and readers from within the U.S.A and abroad will use their vantage points to theorize these distinctions and connections.

In addition to inviting scholars in the U.S.A, I want to reach out to international scholars to consider publishing their work in this journal. I particularly invite the new generation, graduate 
students and junior scholars, to submit their work to $A B O$. Already $A B O$ reaches readers across 130 countries (see the interactive map on our website for the various geographical locations each published piece and the journal reaches). As a scholar who was trained in two academic contexts, Asian and North American, and in three literary traditions, Indian, British, and American, I believe that reaching out—reading new intersections, acknowledging radical differences and finding new connections - rather than only looking inward and demarcating boundaries, invigorates scholarship.

Our digital environment is well suited for scholarship that integrates image, sound, and code with textuality. I also encourage scholars who have already published their work in $A B O$ to utilize its interactive aspect to reach out and connect with their readers and for readers to connect with each other by using our comments and blog space available for each published piece. Our single-blind review process, based on feminist principles, in which the author remains anonymous but reviewers sign their names, emphasizes the constructive nature of scholarly dialogue. As $A B O$ grows, I look forward to continuing on-going discussions and starting new conversations.

Mona Narain

Texas Christian University

\footnotetext{
${ }^{1}$ Jennifer Nash discusses how intersectionality can be reframed as a methodology in "re-thinking intersectionality." ${ }^{2}$ See Lal, McGuire, Stewart, Zaborowska and Pas's discussion of the importance of valuing differences in feminist approaches and histories in "Recasting Global Feminisms," and Jo Reger's discussion of feminist generations and changes in feminist scholarship in "Finding a Place in History: The Discursive Legacy of the Wave Metaphor and Contemporary Feminism."
} 


\section{Works Cited}

Cho, Sumi, et al. "Toward a Field of Intersectionality Studies: Theory Applications, and Praxis." Signs: Journal of Women in Culture and Society, vol. 38, no. 4, Summer 2013, pp. 785810.

Lal, Jayati, et al. "Recasting Global Feminisms: Toward a Comparative Historical Approach to Women's Activism and Feminist Scholarship.” Feminist Studies, vol. 36, no. 1, Spring 2010, pp. 13-39.

Nash, Jennifer C. “re-thinking intersectionality.” Feminist Review, vol. 89, 2008, pp. 1-15.

Reger, Jo. "Finding a Place in History: The Discursive Legacy of the Wave Metaphor and Contemporary Feminism.” Feminist Studies, vol. 43, no. 1, 2017, pp. 193-221.

Rosenthal, Laura J. "Introduction: Recovering from Recovery." The Eighteenth Century, vol. 50, no. 1, Spring 2009, pp. 1-11.

Subrahmanyam, Sanjay. "Connected Histories: Notes towards a Reconfiguration of Early Modern Eurasia.” Modern Asian Studies, vol. 31, no. 3, 1997, pp. 735-62. 